\title{
The Reception of Septuagint Words in Jewish-Hellenistic and Christian Literature
}

\author{
Ed. by Eberhard Bons, Ralph Brucker and Jan Joosten \\ [Die Rezeption von Septuaginta-Wörtern in jüdisch-hellenistischer und christlicher Literatur.]
}

The Reception of Septuagint Words in Jewish-Hellenistic and Christian Literature

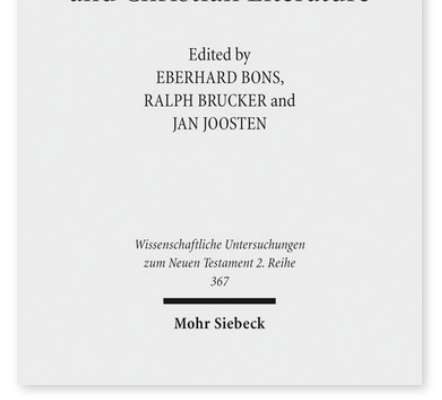

2014. VIII, 213 Seiten. WUNT II 367

ISBN 978-3-16-152954-2

DOI 10.1628/978-3-16-152954-2

eBook PDF 79,00€

ISBN 978-3-16-152953-5

fadengeheftete Broschur 79,00€
Veröffentlicht auf Englisch.

Das geplante Historical and Theological Lexicon of the Septuagint behandelt den Wortschatz der Septuaginta in historischer Perspektive. Hierzu wird die Verwendung der wichtigsten Wörter und Wortfamilien von frühen griechischen Autoren an über nicht-literarische Zeugnisse der Koine, die Septuaginta selbst, bis in jüdisch-hellenistische und frühchristliche Literatur verfolgt. Die letzteren beiden Phasen waren Thema eines Workshops im Jahr 2011, dessen Beiträge in diesem Band veröffentlicht werden. Die Rezeption der Septuaginta im griechischsprachigen Judentum und Christentum wirft viele Fragen auf: Wie wird die unterschiedliche Bedeutung einiger Wörter in ihrer »biblischen« Verwendung im Gegensatz zu ihrer gewöhnlichen Verwendung im Griechischen von den jüdischen oder christlichen Autoren gehandhabt? In welchem Ausmaß haben die Autoren des Neuen Testaments ihre religiöse Terminologie von der Septuaginta übernommen? Welche Wörter der Septuaginta leben mit ihrer spezifischen Bedeutung in späteren jüdischen oder christlichen Schriften weiter - und welche nicht?

Die Beiträge in diesem Band verbinden die Analyse ausgewählter einzelner Wörter oder Wortgruppen mit grundsätzlichen methodischen Erwägungen.

Inhaltsübersicht

Ralph Brucker: A Sample Article: ợ $\delta \omega$ - Christoph Kugelmeier: Kämpfen, Mühsal und Elend in der Septuaginta: Die von $\mathrm{AE \Theta} \wedge-/ \mathrm{A} \Theta \wedge$ - abgeleitete Wortgruppe - Katell Berthelot: The Notion of Anathema in Ancient Jewish Literature Written in Greek

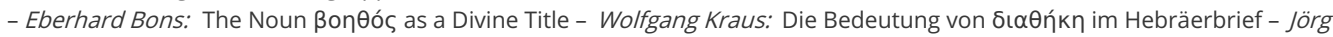
Frey: The Use of $\delta$ '́ $\alpha$ in Paul and John as Shaped by the Septuagint - Jan Joosten: Mixed Blessings: The biblical notion of blessing in the works of Philo and Flavius Josephus - Emanuela Prinzivalli: The Use of ónóvoı $\alpha$ and Related Terms in the Septuagint and in Christian Literature of the First Three Centuries - Enrico Norelli: La Septante dans quelques testimonia non canoniques des origines chrétiennes - Thomas J. Kraus: Eine Grammatik der Septuaginta und des Neuen Testaments: Methodische Überlegungen zu Grenzen und Möglichkeiten - James Aitken: Synthesis

Eberhard Bons Geboren 1958; 1988 Dr. phil.; 1993 Dr. theol.; 2000 Habilitation; seit 2004 Professor für Altes Testament an der Universität Straßburg.

Ralph Brucker Born 1961; 1996 Dr. theol., University of Hamburg; since 2010 lecturer for Old and New Testament at the Justus Liebig University Giessen; since 2011 Post-Doc Research Fellow at the University of Strasbourg.

Jan Joosten Born 1959; Regius Professor of Hebrew, University of Oxford; Student of Christ Church.

Jetzt bestellen:

https://mohrsiebeck.com/buch/the-reception-of-septuagint-words-in-jewish-hellenistic-and-christian-literature-

9783161529542?no_cache=1

order@mohrsiebeck.com

Telefon: $+49(0) 7071-923-17$

Telefax: $+49(0) 7071-51104$ 